\title{
Company Responses to Demands for Annual Report Changes
}

\author{
Riise Johansen, Thomas; Plenborg, Thomas
}

Document Version

Accepted author manuscript

Published in:

Accounting, Auditing and Accountability Journal

DOI:

10.1108/AAAJ-02-2016-2419

Publication date:

2018

License

Unspecified

Citation for published version (APA):

Riise Johansen, T., \& Plenborg, T. (2018). Company Responses to Demands for Annual Report Changes. Accounting, Auditing and Accountability Journal, 31(6), 1593-1617. https://doi.org/10.1108/AAAJ-02-2016-2419

Link to publication in CBS Research Portal

\section{General rights}

Copyright and moral rights for the publications made accessible in the public portal are retained by the authors and/or other copyright owners and it is a condition of accessing publications that users recognise and abide by the legal requirements associated with these rights.

Take down policy

If you believe that this document breaches copyright please contact us (research.lib@cbs.dk) providing details, and we will remove access to the work immediately and investigate your claim. 


\section{Company Responses to Demands for Annual Report Changes}

\section{Thomas Riise Johansen and Thomas Plenborg}

Journal article (Accepted manuscript*)

\section{Please cite this article as:}

Riise Johansen, T., \& Plenborg, T. (2018). Company Responses to Demands for Annual Report Changes. Accounting, Auditing and Accountability Journal, 316), 1593-1617. 00l: 10.1108/AAAJ-02-2016-2419

\section{DOI: 10.1108/AAAJ-02-2016-2419}

This article is @ Emerald Group Publishing and permission has been granted for this version to appear here: https://research.cbs.dk/da/publications/company-responses-to-demands-for-annual-report-changes.

Emerald does not grant permission for this article to be further copied/distributed or hosted elsewhere without the express permission from Emerald Group Publishing Limited.

* This version of the article has been accepted for publication and undergone full peer review but has not been through the copyediting, typesetting, pagination and proofreading process, which may lead to differences between this version and the publisher's final version AKA Version of Record. 


\title{
COMPANY RESPONSES TO DEMANDS FOR ANNUAL REPORT CHANGES
}

\author{
Thomas Riise Johansen \\ Thomas Plenborg \\ Copenhagen Business School \\ Department of Accounting and Auditing \\ Solbjerg Plads 3 \\ DK-2000 Frederiksberg \\ Denmark
}
Phone +4538152320
Fax +4538152321

E-mail:

trj.acc@cbs.dk

tp.acc@cbs.dk

6 November 2017

This paper has benefited from helpful assistance and comments provided by David Vestengen Hopkins, Hans Peter Lindegård Buhrkal, Jacob Mærsk, Morten Lindtner and participants at the Better Business Reporting workshop in Copenhagen and the BIS Narrative Reporting Forum in London. We acknowledge financial support from KPMG. 


\title{
COMPANY RESPONSES TO DEMANDS FOR ANNUAL REPORT CHANGES
}

\author{
ABSTRACT \\ Purpose \\ This paper examines how and the extent to which barriers to change inhibit new ideas about note \\ disclosures to manifest themselves in annual reports.
}

\section{Design/methodology/approach}

The study employs regulation theory and draws on case studies in Denmark and the UK to understand compliance motivations and, on that basis, to identify the barriers to and enablers of changes to note disclosures in annual reports.

\section{Findings}

It is demonstrated how certain characteristics of the annual report preparation process can dampen the potential for change. It is also shown how preparer perceptions of oversight agents (auditors, enforcers, audit committees) have effects on disclosure behaviour. These characteristics appear to cause defensiveness among the actors involved in the process, inhibiting changes. In contrast, enablers are related to trust in regulatory enforcement, facilitation from enforcers, user orientation and shared understanding among functional groups involved in the preparation process.

\section{Practical implications}

The preparation of notes is susceptible to the influence of a range of factors, such as company politics, perceptions of enforcement styles and actors' concerns about being blamed for inappropriate responses to regulation. These findings could be considered by regulators, auditors and preparers in enhancing understanding of their respective roles in the annual report preparation process.

\section{Originality/value}

This study illuminates the conditions that facilitate change when new ideas are introduced to a highly normative and detailed field. The study contributes to previous research by providing a fieldworkbased analysis of the practices, judgements, discussions and actors involved in the preparation of note disclosures.

Keywords: Annual report, IFRS, Notes, Compliance motivations 


\section{INTRODUCTION}

The notes to the primary financial statements have appeared to be an increasingly significant part of the annual report, both in terms of volume and in terms of the resources spent on producing this part of the annual report. Items disclosed in the notes complement the primary statements by providing information on details (including disaggregation), assumptions, judgements, risks, claims and rights in relation to line items or unrecognized items. Within IFRS, the preparation of note disclosures is prescribed in great detail in standards such as IFRS 3 (business combinations), IFRS 7 (financial instruments) and IAS 36 (Impairment of assets). Financial reporting enforcers as well as auditors further assess specific company disclosures against requirements. The combination of detailed prescriptions and perceived expectations from the external environment (e.g., enforcers, auditors and investors) creates an impression of a highly normative field, which prescriptively directs the manner in which disclosures are prepared in the notes.

Since 2011, standard setters, preparers and professionals have levelled serious critiques of note disclosure practices (EFRAG et al., 2012; FRC, 2012; IAASB, 2012; IASB, 2014; IASB, 2015; NZCA and ICAS, 2011; Spencer, 2014). The concern is that note disclosures have become overly complex, excessive and burdensome and that the amount of immaterial information provided therein has increased. Suggested solutions have included 'cutting clutter' from annual report disclosures, applying professional judgement when responding to disclosure requirements, proactively using the materiality concept in disclosure preparation and having standard setters replace the arbitrary development of disclosure requirements with a more conceptual standard-setting approach to disclosure requirements (Barker et al., 2013; EFRAG et al., 2012; FRC, 2011; IASB, 2015; ICAEW, 2013; NZCA and ICAS, 2011). The anticipated results of such changes could include a reduction in the burden of disclosure preparation and an increase in the quality of the annual report via better presentation of disclosures, greater emphasis on disclosures perceived to matter and less emphasis on disclosures perceived to be 'boilerplate' or less material.

This paper seeks to understand the enablers of and barriers to intervention in such a normative field. The initiatives mentioned above seek to intervene by identifying a need for companies to change their approaches to the format and content of the notes and encourage them to do so within the current regulatory framework. Accordingly, and in response to calls for research on the preparation process by which financial accounts are constructed (Robson et al., 2017), the research question is how and the extent to which barriers to change inhibit new ideas about note disclosures to manifest themselves in annual reports. In doing so, we conduct case studies based on empirical data at a point in time, 2012, when these ideas were well known but also had just been introduced to preparers in the annual reporting field. The study is based on a comparison between case studies in Denmark, where companies tend to resist responding to the developments described above, and case studies in the UK, where a number of companies have appeared to be receptive to such developments by implementing changes to the form and content of the notes section.

This study posits that variations in disclosures are the products of how companies respond to regulations and the motivations underlying these responses. Compliance motivations (Etienne, 2011; May, 2004) are interesting to study because they can lead to variations 
(Edelman and Talesh, 2011) in how companies comply with disclosure regulations. To further understand company responses, the study attempts to identify the factors that might drive or dampen annual report innovations and modifications. This endeavour requires consideration of the process by which the annual report is prepared, the actors involved in this process, external parties (such as auditors, consultants, analysts and enforcers) that interact with company staff, and the templates, checklists and guidelines that shape the disclosures and choices made during this process. The aim of the paper is thus to study the micro-level responses to regulations and their responses to the perceived need for companies to change the annual report form and content while maintaining compliance with accounting regulations.

The analysis offers evidence about the factors that can lead to scenarios in which a) companies choose to comply defensively with IFRS disclosure requirements, although a departure from rules might be justified on materiality grounds; b) materiality judgements are limited; and c) note disclosure remains the same despite company perceptions of a clear need for change. In light of cases in which some changes to the notes section have been implemented, the analysis shows that these barriers are related to the behaviour of both regulators and auditors, different conceptions of materiality, limitations to the preparation process, a limited understanding of users' information needs and, in a related vein, a preoccupation with adhering to regulations for the sake of compliance.

This study makes two significant contributions. First, it supplements the scant existing qualitative research on financial reporting practices. Although previous interpretive research has examined the accounting standard setting (Robson and Young, 2009), few interpretive studies have addressed the financial accounting practices, processes, judgements and decisions underlying annual reports (Cooper and Robson, 2006; Hatherly et al., 2008; Huikku et al., 2017; MacKenzie, 2008; Robson et al., 2017). Thus, there is a need for empirical research that goes beyond the compliance/non-compliance dichotomy and focuses on the manner in which preparers comply (Chahed and Goh, 2016; see also Edelman and Talesh, 2011) and how financial reports are collectively constructed (Robson et al., 2017). In particular, this study provides insight into the construction of a defensive environment surrounding the preparation of notes and insights into the conditions that could replace defensiveness, with a focus on the materiality of disclosures, as well as on the primary users of financial reporting, as opposed to secondary foci, such as how disclosures are perceived by regulators, auditors and internal constituencies. Second, this study addresses the interpretation, implementation and enforcement of accounting rules between two countries. The intention is to illuminate the interrelationships among macro-level institutions and micro-level actors and activities, which have attracted limited attention in the financial reporting research (Chahed and Goh, 2016; Lounsbury, 2008). As such, the study adds to the previous qualitative research on financial reporting enforcement, which was conducted in the pre-IFRS environment (Fearnley et al., 2000; Fearnley et al., 2002; Hines et al., 2001). This contribution provides practical insights into the role of the regulatory environment in the 'production of normativity' (Bebbington et al., 2012). In making this contribution, the study integrates regulation theory on compliance motivations with the financial reporting field to show why certain companies tend to take conservative approaches to the annual report form and content, whereas other companies are less conservative. 


\section{PREVIOUS LITERATURE AND ANALYTICAL FRAMEWORK}

This section seeks to outline an analytical framework for how and why companies might respond differently to regulation in general and to the regulation of note disclosures in particular. Of particular interest are the factors and regulatory practices that affect motivations for regulatory responses and how previous financial accounting research relates to such factors and practices.

\subsection{Analytical framework for how companies respond to note disclosure regulations} The potential for and the manner in which established patterns of behaviour and templates of practices related to note disclosures might change are areas in which the deployment of institutional theory is obvious. This deployment could occur through the study of the processes by which institutional fields change (Greenwood et al., 2002), through a focus on the institutional work performed to change a field (Canning and O'Dwyer, 2016), or through a focus on the role of institutional entrepreneurship (Covaleski et al., 2013; Greenwood and Suddaby, 2006). As such, this objective aligns with Greenwood et al. (2002) and similar institutional theorization in that the research question of this study warrants a focus on the pressures for change, in this case the changing format and content of note disclosures, and their justification in highly normative settings, in this case a setting with detailed IFRS regulation and an assortment of oversight agents (auditors, enforcers, audit committees).

Aligned with these theoretical perspectives, this paper focuses on the social constitution of regulation (Bozanic et al., 2012; Cohen et al., 2013; Covaleski et al., 2013; Edelman and Suchman, 1997) with a particular focus on the normative setting in which actors respond to regulatory requirements. The aim is not to reveal whether regulation is captured or not at the organizational level but to acknowledge that the enactment of regulation is socially constructed and that it is relevant to focus on the processes by which actors mediate the impact of regulations.

This paper draws more specifically on regulation research, in which analytical frameworks have been developed to explain and provide an understanding of behaviours and motivations of regulatees. This research area includes studies of motivational postures (Braithwaite et al., 2007), how the variations in and framing of goals relate to responses to regulations (Etienne, 2011), the affirmative and negative bases of compliance motivations (May, 2004) and the role of the "corporate social license" in regulatory responses (Gunningham et al., 2004). As Black (2008a) noted, this line of research has much in common with the institutional strand of organizational behaviour research focusing on organizational responses to institutional processes (Goodstein, 1994; Oliver, 1991). What is interesting is not the extent to which companies align with coercive pressures, such as regulations, but rather the manner and strategies adopted by companies to respond to regulatory requirements. Financial accounting research has to some extent considered these perspectives (Alon, 2013; Berland et al., 2015; Carpenter and Feroz, 2001; Guerreiro et al., 2012).

This paper focuses on different company responses to annual report regulations pertaining to note disclosures to understand the barriers to and enablers of annual report reform. Because the aim is to develop an understanding of behaviours within the boundaries 
established by regulations, matters related to non-compliance are not a key area of focus. The compliance motivation framework outlined by May (2004) seems to be useful for the purposes of this paper. This framework serves as an 'informing theory' (O'Dwyer and Unerman, 2014) or 'method theory' (Lukka and Vinnari, 2014) and is selected based on its fit with the research aim and because it augments a theoretical contribution when theories from other fields are integrated with the financial reporting field (Corley and Gioia, 2011, p. 19; O'Dwyer and Unerman, 2014, p. 1230). ${ }^{1}$

Like Bozanic et al. (2012), who took the 'endogenization view' on regulation as an extension of institutional perspectives on regulations, we view the compliance motivation approach as a variant of the endogenization view, and thus an institutional approach, because in essence it is concerned with processes of institutionalization. The approach is similar to those of Edelman and Suchman (1997) and Bozanic et al. (2012) in the focus on how multiple actors might be involved in institutionalization processes, but it is different in that it does not focus on how regulatees could capture regulation but rather on how actors respond to and adopt regulations. As suggested by Gilad (2014), this focus appears to provide a more balanced view on how multiple actors co-construct the meaning of regulation. It is furthermore similar to what Bebbington et al. (2012) understood to be the production of normativity.

May (2004) distinguished between affirmative and negative motivations for complying with regulations. Affirmative motivations tend to relate to a positive sense of obligation to comply and to a belief that regulatory compliance can generate advantages beyond being compliant. For example, a company might respond to regulations to earn the respect and approval of stakeholders and other actors, in addition to the regulators that enforce regulations (Hooghiemstra and van Ees, 2011). According to this view, there are shared ideas between regulators and regulatees about the benefits of regulation (May, 2004). Negative motivations focus on the consequences of being detected and subsequently punished for non-compliance. This regulatory style is based on a deterrence model, which suggests that regulatees will comply with regulations only if they are otherwise likely to face adverse consequences (May, 2004). May (2004) noted that, according to this view, greater compliance is achieved by increasing and reinforcing the fear of the consequences for being identified as non-compliant.

It is unlikely that specific responses to regulation can be clearly labelled as driven by either affirmative or negative motivations. Rather, both motivations are likely to be present in varying degrees. It is important to consider the motivations for responses to regulations because different motivations can produce different outcomes. Regulatory scholars seem to agree that negative compliance motivations, at their extreme, are generally ineffective in producing desirable outcomes and that affirmative motivations should be encouraged in such cases (Braithwaite et al., 2007). As Hooghiemstra and van Eees (2011) suggested, when negative motivations drive company responses to disclosure regulations that are characterized as flexible, non-prescriptive and principles-based, disclosures tend to become uniform and boilerplate and to lack consideration of the 'spirit' of the regulation (see also Cohen et al., 2013). This outcome is further predicted by the legal endogeneity model (Bozanic et al., 2012; Gilad, 2014) and the 'principles paradox' (Black, 2008b; Schwarcz, 2009). Thus, although the distinction between affirmative and negative bases might be stylized, this concept appears to be useful for 
considering how the factors that influence responses to regulations are related to motivations for regulatory responses.

According to May, regulatory research has identified three sets of factors that influence the manner in which regulatees respond to regulations: (1) regulatory practices; (2) the beliefs and attitudes of regulatees; and (3) the ability and constitutive factors of regulatees to respond to regulations. These influences are outlined and related to accounting research in the following three subsections.

\subsection{Regulatory practices: enforcers and auditors}

Rigorous and frequent inspections that increase the likelihood of sanctions can provide a deterrent effect and thus fuel negative motivations for compliance. May (2004) further emphasized that the enforcement style of inspectors affects compliance motivations. Enforcement styles include both formal communications and actions and informal mechanisms, such as education, advice, debates and negotiations (Baldwin et al., 2011: 238). Inspection practices conducted in a friendly and facilitative manner can foster affirmative compliance motivations, whereas formal, rigid and threatening inspections that preclude dialogue are more likely to produce negative compliance motivations. May (2004) suggested two dimensions by which enforcement styles can be characterized: 1) the degree of facilitation (ranging from helpful and friendly to uncooperative and threatening); and 2) the degree of formalism (ranging from flexible and temperate to rigid and exacting) (see May and Winter, 2011 for further elaboration).

Regulatory practices appear in the annual reporting field through national enforcement practices, as well as the role of auditors. Previous archival-based accounting research has focused less on enforcement styles and more on the strictness of enforcement. Glaum et al. (2013) found considerable cross-country variation in disclosures pursuant to IFRS 3 (business combinations) and IAS 36 (impairment of assets) and attributed this variation to country-specific regulatory practices, including the strictness of enforcement (see also Hope, 2003). Bischof (2009) distinguished between principles-based enforcement and rules-based enforcement in a manner comparable to the formalism dimension mentioned above. Without claiming that either rules- or principles-based enforcement works best, Bischof (2009) studied the adoption of IFRS 7 by European banks and concluded that the national approach to enforcement impacts the results (see also Cohen et al., 2013).

Qualitative research conducted in the UK context has demonstrated not only that enforcers and companies tend to have very different views of financial reporting issues, such as materiality (Fearnley et al., 2000), but also that there might be a tendency to mythologize enforcers, which could be due to the perception that enforcers overreact to minor issues (Hines et al., 2001). Fearnley et al. (2002) and Beattie et al. (2011) further illustrated that, in client negotiations, auditors are likely to draw attention to the risk of error detection by enforcers and thereby to reinforce the enforcement style. This finding is consistent with research suggesting that, under regulatory pressure or uncertainty about the rules, professionals could be engines of a process that leads to formal structures, mechanical responses to regulation and an emphasis on the appearance of compliance (Bozanic et al., 2012; Cohen et al., 2013; Gilad, 2014; Gué-Paracini et al., 2014). This outcome is, according to Power (2004b; 2007), explained by the legal and reputational 
consequences of error identification, inappropriate rule following or other failures, which resemble the negative base of compliance (May, 2004). A preoccupation with legal and reputational risks and a tendency towards the negative base of compliance motivation are likely to bring about formal and ritualistic modes of compliance (Gibbins et al., 1990; May, 2004; Power, 2004a; Sunder, 2010). This preoccupation is therefore quite unproductive and inward looking (Power, 2004a: 25).

\subsection{Beliefs and attitudes}

According to May's (2004) line of thought, regulatees' trust in regulatory practices depends on the extent to which they can rely on the messages and signals from regulators. Such messages and signals might be threats, promises or consistent behaviours, and the trustworthiness of these messages and signals enhances compliance motivations. Depending on the nature of the messages and signals, this enhancement might be related to either affirmative or negative motivations.

Regulatees are likely to develop views on regulation (e.g., disagreement, irritation or acknowledgement), and rules and guidance from regulators might be viewed as more or less legitimate and fair. Although it is unclear whether this view affects negative compliance motivations, the perceived legitimacy of regulation likely inspires affirmative motivations (May, 2004). This impact on affirmative motivations was demonstrated by Bebbington et al. (2012), who compared how two national reporting regimes, Spain and the UK, differ in terms of whether actors come to view rules as binding. They showed that the motivations of regulatees influenced the construction of a normative climate because reporting regulations were more successful in the setting in which the regulations were viewed as legitimate.

In addition to views about regulation and regulatory practices, regulatees might have various beliefs about the benefits of responding to regulations. Such benefits are often reputational in nature (May, 2004), although other economic incentives for compliance could exist, such as 'peer effects' (Weaver, 2014) or rewards and the relief of other burdens, such as avoiding more direct scrutiny by regulators (Baldwin et al., 2011). A key driver of company responses to disclosure requirements appears to be whether companies perceive benefits beyond merely appearing compliant. These reputational concerns enhance affirmative motivations for compliance. This effect has been demonstrated by the literature on the voluntary adoption of disclosure regulations (Guerreiro et al., 2012) and studies related to the disclosure of non-financial information (Cormier et al., 2004; Cormier et al., 2005). Regulators have also attempted to outline the company-level benefits of complying with regulations (e.g., EFRAG and ASB, 2011; IASB, 2011). Furthermore, there is a large body of evidence suggesting that the format and content of disclosures are significant to users and therefore benefit regulatees (e.g., Barker et al., 2013; Beattie, 2014; Fox and Cooper, 2015; Leuz and Wysocki, 2016).

\subsection{Abilities of regulatees}

Factors related to the ability to comply might also enhance or constrain the affirmative and normative bases of compliance motivations. Such factors can be separated into two distinct groups: those related to structure and processes; and those related to behaviour. 
Factors related to structure and processes include the preparation process, the cost of disclosure and the complexity of disclosure. The preparation process was defined by Gibbins et al. (1990, p. 126) to include "all activities and procedures, the individuals or groups involved, the alternatives considered, the timing and sequence of events, and the threads and connections among people and events". As Lantto (2013) showed, the structure of the preparation process is shaped by both regulations and responses to regulations. The division of decision-making responsibilities among staff at different hierarchical levels should also be considered but has rarely been included in previous research (Hatherly et al., 2008). This gap in the literature is unfortunate because there seems to be a disconnect between what standard setters and others expect (namely that senior managers make key decisions) and how actual accounting and disclosure decisions are made (i.e., in many cases by lower-level staff) (Fox and Cooper, 2015; Hatherly et al., 2008; Leung, 2011).

Behavioural factors include organizational competencies/knowledge, personal preferences and internal politics (Gibbins et al., 1990). The roles of the personal preferences of senior managers or other staff have been inferred indirectly by archivalbased research, suggesting that manager or director characteristics (e.g., executive pay or director independence) influence disclosure outcomes (e.g., Eng and Mak, 2003). Field studies have observed how opportunism interferes with the financial reporting process, as dominant board members or executives reject other beliefs based on their own convictions (Adams, 1997; Berland et al., 2015; Gibbins et al., 1990). Other studies focusing on non-financial disclosures have suggested that the personal advocacy of senior-level staff is a driver of or restraint on the development of disclosures (Cormier et al., 2004; Gray et al., 1990; Martin and Hadley, 2008; Quaak et al., 2007). Previous research has also identified internal politics as having a significant impact on disclosure choices (Adams, 1997; Berland et al., 2015; Gibbins et al., 1990; Mayorga, 2013).

\section{RESEARCH METHODS}

\subsection{Case studies and research context}

This paper is based on qualitative studies of annual report preparation in four cases in Denmark and two cases in the UK. The case study approach is appropriate because prior research is limited. The objective of studying multiple cases is to compare perceptions and responses across case organizations and among actors with different backgrounds. In addition, the aim of studying cases in two national contexts is to understand how elements of culture, specific debates and the wider context (related to enforcement in particular) might impact how and why preparers respond to regulations about note disclosures. Taken together with the below-mentioned case characteristics, the case selection aimed at providing an empirical basis for the intended contributions, namely, to integrate regulation theory with empirical material to enhance understanding of the financial reporting environment related to note disclosures.

The Danish case companies have several characteristics that make them suitable for this study: a) they are among the largest companies listed on the Nasdaq Copenhagen stock exchange in terms of market value; b) they have considerable analyst coverage and 
liquidity, and therefore their annual reports should have interested users; and c) they have over the years consistently participated in annual report award schemes and are viewed as preparers that maintain and/or develop annual reports as an important medium for reporting to stakeholders. Despite this apparent focus on the annual report, none of the four case companies have significantly altered the content or structure of their annual reports in recent years.

The two case companies from the UK were selected on a different basis than the Danish companies. In the UK, the intention was to include companies that work actively to change the form and content of the annual reports, including the notes section, and that appear responsive to calls for change. This choice implies that both UK companies made substantial changes to the notes section of their annual reports in the most recent financial year before the year of data collection.

The empirical material for the case studies was collected in 2012, when new ideas about note disclosures were sought and promoted. These ideas included debate over the form and content of the notes section and the annual report in general, mainly initiated by the UK regulator (e.g., FRC, 2009; FRC, 2011; FRC, 2012). This debate also occurred in Denmark and was mainly been promoted by individual accountants looking abroad for inspiration and because of activities (such as conferences, award schemes and publications) supported by accounting firms.

Listed companies were largely subjected to similar regulation and enforcement of note disclosures between the two countries. Because both countries are EU member states, the overall EU requirement to establish an enforcement authority, cf. recital 16 of the EU IFRS regulation, applies to both countries. The enforcer in 2012 was Fondsrådet in Denmark and FRRP (Financial Reporting Review Panel) under the FRC in the UK. Both enforcement authorities participate in EECS (European Enforcers Coordination Sessions), which is a group under ESMA in which member state authorities exchange views on and coordinate financial reporting about enforcement. The standards CESR no. 1 and 2, issued by the predecessor to ESMA, guide enforcement in both countries, including, e.g., scope, sampling and corrective measures. These standards are however voluntary, indicating that there might be some differences between the countries in how enforcement is conducted. Enforcement authorities in both countries can influence financial reporting behaviour in general because both of them regularly issue reports, guidelines and enforcement letters in specific cases. Regarding the regulation of note disclosures in 2012, as well as in the years before and after the data collection, the case companies in the two countries faced similar regulations, including a range of IFRSspecific disclosure requirements that are stipulated. ${ }^{2}$

\subsection{Data sources}

\section{Archival data}

Multiple archival sources were used to develop an understanding of the annual reporting field and to develop interview guides. These sources included discussion documents, reports and standard-setting activities of Danish and UK authorities, including the Danish Business Authority, Fondsrådet (enforcement body) and Institute of State-Authorized Public Accountants in Denmark and the FRC and Department of Business, Innovation 
and Skills (BIS) in the UK. Sources also included documents from: EFRAG, which has been eager to promote a debate about disclosures in the notes section; IASB, which has added a disclosure project to its agenda; and IAASB, which has questioned the value of disclosures in the notes section. In addition, annual reports from case companies, as well as documents and regulations related to the establishment and functioning of enforcement activities in the two countries, were reviewed.

\section{Interviews}

The sampling of interviews was guided by the intent to include views from actors who influence the preparation of annual reports and, in particular, disclosure choices and the preparation of disclosures in the notes. In total, 32 interviews were conducted with individuals representing preparers, financial analysts, auditors and enforcement staff (see table 1). The enforcement staff was related to the FRC (UK) and Fondsrådet (Denmark).

Table 1. Interviewees

\begin{tabular}{clll}
$\begin{array}{c}\text { Code for } \\
\text { interviewee }\end{array}$ & Interviewee & & National context \\
\cline { 1 - 1 } A1 & Head of IR at case company A & & Denmark \\
A2 & Head of group consolidation at company A & Denmark \\
A3 & Responsible for IFRS compliance at company A & Denmark \\
B1 & Head of IR at company B & Denmark
\end{tabular}




\begin{tabular}{lll} 
B2 & Head of group accounting at company B & Denmark \\
B3 & Project manager in finance department at company B & Denmark \\
C1 & Head of IR at company C & Denmark \\
C2 & Director in finance department at company C & Denmark \\
C3 & Head of group reporting at company C & Denmark \\
D1 & IR manager at company D & Denmark \\
D2 & Head of group accounting at company D & Denmark \\
E1 & Head of IR at company E & UK \\
E2 & Head of financial reporting at company E & UK \\
F1 & Head of IR at company F & UK \\
F2 & Head of group accounting at company F & UK \\
X1 & Analyst following company A & Denmark \\
X2 & Analyst following company A & Denmark \\
X3 & Analyst following company B & Denmark \\
X4 & Analyst following company B & Denmark \\
X5 & Analyst following company C & Denmark \\
X6 & Analyst following company C & Denmark \\
X7 & Analyst following company E & UK \\
X8 & Analyst following company E & UK \\
Y1 & Audit partner & Denmark \\
Y2 & Audit partner & Denmark \\
Y3 & Audit partner & Denmark \\
Y4 & Audit partner & Denmark \\
Y5 & Audit partner & UK \\
Z1 & Member of enforcement body & Denmark \\
Z2 & Senior official at enforcement authority & Denmark \\
Z3 & Official at enforcement authority & Denmark \\
Z4 & Senior official at enforcement authority & UK \\
\hline & & \\
\hline
\end{tabular}

Each case was approached with the aim of identifying the staff directly involved in and responsible for disclosure considerations in the annual report. In most cases, staff in the finance and investor relations (IR) departments was identified. In addition, it was possible in most cases to interview two analysts that followed the specific case company. Analysts are considered the most active and observant group of annual report users. Moreover, they are a significant information intermediary in the financial reporting supply chain and are likely to represent disclosure demands from annual report users (e.g., Beyer et al., 2010; Johansen and Plenborg, 2013).

Interview guides for finance staff, investor relations and analysts were customized with questions related to reports from the case company. The annual reports of each case company, for the past three years before the study, were reviewed. This review included mapping the contents of each annual report and identifying significant disclosure items and changes over the years. The review of previous reports was conducted prior to the interviews, allowing the researchers to connect interviews to the specific company context using specific disclosures, or disclosure changes, as points of departure for 
interview questions. This approach forces interviewees to go beyond overly general prepared responses that merely repeat widespread beliefs (Chell, 1998; Kvale, 1996). In addition to researcher identification of specific disclosures before the interview, some questions allowed the interviewee to identify specific disclosures for discussion. For example, disclosures which the interviewee would like to change. Interview questions focused on understanding the study phenomena, including the interviewee's role in relation to the annual report and the specific note disclosures, motivations and processes underlying specific changes made/not made and views about ideas and recommendations present in the annual reporting field. A set of questions further focused on understanding the factors that had effects on study phenomena, including views about how authorities (auditors and enforcement), internal politics, disclosure requirements, materiality assessments and preparer-user interactions are related to the annual report/specific disclosures from the case company.

Interviews with auditors and enforcement authorities were not closely tied to a specific case company context, although some questions included examples from case companies. The identity of the case companies was not revealed to auditors and enforcement authorities. These interviews attempted to draw out views and experiences on auditing/enforcement of disclosures. Questions for the auditors included views about the auditing of note disclosures, interactions with the client staff/IFRS specialists/enforcement authorities, views about developments in the reporting field, experiences with changing of the form and content of notes and the role of materiality assessments in discussions with clients. Questions for enforcement authorities included the overall role and process of financial reporting enforcement, views about the impact of enforcement authorities on the reporting field, the role/possibility of materiality assessments regarding note disclosures, views and experiences with annual report changes among the entities under enforcement and interaction/dialogue with companies and auditors on disclosure issues. Interviews were conducted with audit partners from the Big Four accounting firms and with senior staff from enforcers in the two countries because these actors are likely to affect preparers' responses to regulation.

\subsection{Data analysis}

The interviews were transcribed and subjected to analysis in stages. The linking of empirical observations with the case context and theoretical themes was ongoing and was subjected to analysis as the interviews and data collection progressed (Baxter and Chua, 1998). On the basis of all of the interview transcriptions, a more holistic and mainly descriptive coding technique was implemented using data analysis software to enable different displays of the data and to provide an overview of the material. Next, a more theoretically informed analysis was conducted according to the analytical framework presented in section 2. In this regard, the compliance motivation framework is considered a "skeletal" theory, and the goal was to put "flesh" on this skeleton (Laughlin, 1995). This process included both descriptive and interpretive coding, and it drew on the archival material to identify and interpret preliminary patterns and themes. As a result, the data were gradually displayed and reduced (O'Dwyer, 2004). On this basis, the findings were written up and presented at a small group seminar that included several case companies, at an open conference for practitioners and at a workshop that included both regulators 
and companies. These presentations added to the descriptive and interpretive findings and refined the analysis.

\section{EMPIRICAL FINDINGS}

The findings are presented in four subsections. The first subsection presents the changes to the notes section that were made to or considered in the annual reports of the case companies. This subsection is followed by three subsections that present the empirical analysis according to the theoretical framework: regulatory practices, beliefs and attitudes, and abilities.

\subsection{Changes in the annual reports of case companies}

As mentioned in the introduction to this paper, there has been significant debate over note disclosures, indicating a perceived need to change disclosure practices. The debate over annual reports in the UK was rather well known among the interviewees in Denmark, and accounting firms were the strongest proponents of change. In the UK cases, which represented significant annual report changes, the concern was that annual reports had lost relevance, and actors thus aimed at repositioning the annual report as a key document for investors.

\footnotetext{
When we go to meet shareholders, and we have IR meetings, it is the presentation we discuss, not the annual report. This is wrong. It shows how annual reports and particularly IFRS have driven disclosures in formats that actually hinder comprehension of the true performance of a business. (E1)
}

Despite similar thoughts about the need to change the annual reports in the Danish cases, no significant changes have been made. Each interviewee from the Danish companies had issues that they would like to change. In particular, interviewees reiterated the disclosure overload theme and the missing links between the first part of the annual report and the notes section.

Table 2 provides some of the most significant examples of changes being considered and changes that were made.

Table 2. Examples of annual report changes implemented or considered by case companies

\begin{tabular}{|l|l|l|l|l|l}
\hline Company A & Company B & Company C & Company D & Company E & Company F
\end{tabular}




\begin{tabular}{|c|c|c|c|c|c|}
\hline $\begin{array}{ll}\text { - } & \text { Considered } \\
\text { adding more } & \text { detail } \\
\text { regarding } \\
\text { operating } \\
\text { segments } \\
\text { - } & \text { Considered } \\
\text { providing } \\
\text { more detail } \\
\text { on } \\
\text { management } \\
\text { remuneration } \\
\text { Several } \\
\text { disclosures } \\
\text { in notes were } \\
\text { considered } \\
\text { immaterial } \\
\text { but were } \\
\text { maintained } \\
\end{array}$ & $\begin{array}{l}\text { - } \text { Several } \\
\text { disclosures } \\
\text { in notes } \\
\text { were } \\
\text { considered } \\
\text { immaterial } \\
\text { but were } \\
\text { maintained }\end{array}$ & 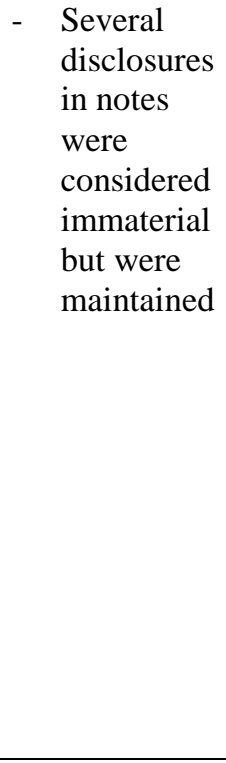 & $\begin{array}{l}\text { Several } \\
\text { disclosures } \\
\text { in notes } \\
\text { were } \\
\text { considered } \\
\text { immaterial } \\
\text { but were } \\
\text { maintained } \\
\text { Considered } \\
\text { providing } \\
\text { only text, } \\
\text { and not } \\
\text { numbers, } \\
\text { for some of } \\
\text { the notes } \\
\text { that were } \\
\text { considered } \\
\text { immaterial }\end{array}$ & 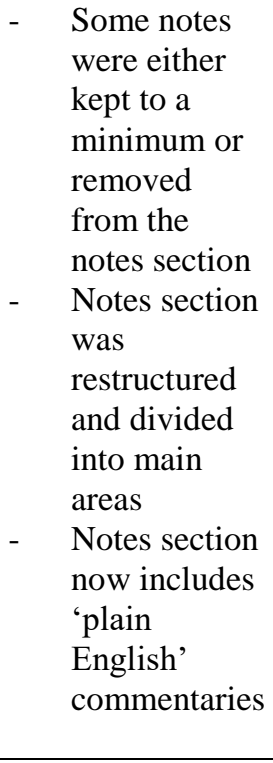 & 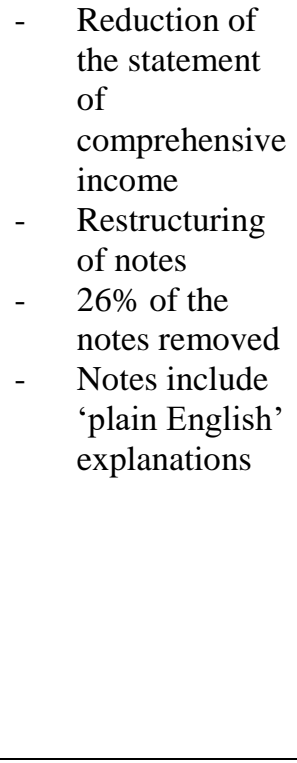 \\
\hline
\end{tabular}

\subsection{Regulatory practices}

\subsubsection{Perceptions of the enforcement behaviours of regulators and auditors}

Studies have indicated that the annual report preparation process is heavily influenced by specialist consultants, including public relations firms, communications experts and lawyers (Chahed and Goh, 2016; Gibbins et al., 1990). However, such influences were not found in any of the six case studies. Rather, the primary external influences on the studied companies appeared to be their auditors and regulators.

Company staff in the four Danish cases generally perceived auditors as quite conservative, focused on painstaking reviews of note disclosures with checklists of disclosure requirements and obsessed with avoiding the risk of deficiency detection by the enforcer:

I believe that auditors use enforcers as an excuse for requiring all kinds of disclosures in the annual report. [...] However, this is too easy for the auditors. (C2)

The interviewed auditors from Denmark were aware that they conduct a rigorous IFRS review process, involving not only the client engagement partner but also IFRS specialists. This practice was designed to avoid attention from enforcers.

Compliance is important. The worst thing you can experience as an auditor is having your client reported to the enforcement authorities. If that happens, you can be sure that you will end up in front of the disciplinary board for auditors. (Y1)

We are very aware that the enforcer operates with a very low materiality threshold. This obviously affects what we expect from our clients. Although we may have a view of disclosure materiality that deviates from enforcers, we still apply the low level of materiality suggested by enforcers. At the end of the day, we will be fined if enforcers disagree. (Y2) 
The IFRS review process is based on disclosure checklists, which all of the Big Four accounting firms produce. Company staff members also use these checklists to prepare for IFRS reviews conducted by auditors. The auditors themselves admit that the widespread use of IFRS checklists inhibits annual report innovation:

If you aim for innovation, then the checklist is not helpful. You can be innovative if inspired by others -- if you engage in careful reflection and then evaluate what meets your needs. The checklist clearly does not help in this context. (Y4)

The audit firms appointed by the UK companies conducted similar reviews, and both UK case companies experienced extensive examinations by the IFRS specialists from their respective audit firms, who wanted to ensure that none of the modifications to the annual reports could be interpreted as non-compliance by the enforcer:

They had an early technical review by their own technical guys. They were quite heavily involved behind the scenes in making sure we were compliant with all of the standards and making sure that we wouldn't cut anything out that we shouldn't. (F2)

Departures from specific disclosure requirements can be justified under IFRS if such disclosures are immaterial (IAS 1, paragraph 31). Thus, materiality can serve two technical roles: reducing the administrative burden; and enhancing the disclosure quality (Edgley, 2014). The Danish cases referred to the non-existence of materiality judgements as one of the main causes of their limited interest in reducing clutter and changing the notes:

It is obvious that we would like to remove many of the notes in which we ask, "Why on earth is this important?" [...] The enforcer is the only reason for including those notes. We never discuss IAS 1 [paragraph 31] because the enforcer's interpretation of materiality is so different from ours or, in fact, is non-existent. (A2).

It is not surprising that different constituencies have different views of materiality (Edgley, 2014). What is interesting is not the different beliefs of the various constituencies regarding the information that should be included and what should be eliminated based on materiality judgements but rather that the perceived risk of litigation seems to limit the use of materiality judgements. As expected (Schipper, 2007), these perceptions are primarily found among auditors and appear to be based on anticipated enforcer behaviour.

Enforcers in the UK and Denmark have different views regarding departures from laws and standards when such departures are justified on materiality grounds. These differences might be rhetorical, but nonetheless they reflect how 'proper' responses to accounting standard requirements are articulated by enforcers in the UK, for example.

In preparing financial statements, achieving a true and fair view is and remains the overriding objective (and legal requirement). In the vast majority of cases, compliance with accounting standards will result in a true and fair view. However, where compliance with an accounting standard may not achieve that objective, accounting standards expressly provide that that standard may be overridden. (BIS, 2013)

The main theme of the Danish enforcers is that disclosure requirements in IFRS and national legislation are material and that 'departures made on purpose' must be combined with a 'defence file' that justifies these departures and provides convincing evidence that the departures are immaterial ${ }^{3}$. The Danish interviewees considered materiality 
judgements to be cumbersome and therefore rarely applied them. It is easier to follow every disclosure requirement than to consider whether to depart from requirements that might be considered immaterial.

Interviewees in the UK expected enforcers to have a positive attitude towards fundamental changes in annual reports if such changes were aligned with current debates:

\begin{abstract}
We had gone through the process, and we referenced one of their publications to explain why we had done what we did: "You told us to cut the clutter out; here you go". Obviously, it is natural to be concerned about receiving an FRC letter, so we do everything we can to make sure that we get our accounting right from the outset. (F2)
\end{abstract}

The UK regulator confirmed in an interview that none of the UK companies that significantly changed their reports was subjected to criticism. Interestingly, the assurance that the regulator would not punish innovative companies was not provided via regulatorregulatee dialogue, and none of the companies had pre-clearance for any of the changes made. Indeed, pre-clearance on disclosure choices (i.e., formal regulator acceptance) is not possible in the UK enforcement system. The only example of direct dialogue with the regulator was an exchange between the regulator and one of the auditors:

Unofficially, there was a direct dialogue with our technical people. The FRC did not see anything before it was published but knew that if [the company] published these documents, and the first thing the FRC did was to send a 20-page letter describing all the deficiencies in them, they were going to kill their own project. You cannot just put two documents out there, 'Cutting clutter' and 'Louder than words', and then punish the companies that try to comply with them. (Y5)

Thus, the issuance of publications that problematized current practices and offered recommendations for annual report changes seemed to be quite powerful in creating a normative climate (Bebbington et al., 2012), including changing attitudes towards whether annual reporting can change while maintaining compliance with regulations. The other UK case company also referred to FRC publications as creating a space for significant changes in the annual report:

The decluttering exercise was quite important for us. It really gave a hook for us to go about the process we already thought we wanted to do. So we had already come up with the thought that we wanted to cut some of the information that we did not think was useful to the reader, but the issuance of the document by the FRC really helped us to push it forward with people like the audit committee and to show that there was a reason for doing it. (E2)

Interviewees from the UK regulator and the UK case companies were also convinced that certain companies trying to incorporate the suggestions contained in the FRC discussion papers protected the companies from subsequent allegations of financial reporting deficiencies. Thus, the FRC publications legitimized changes in annual reports.

The annual reports from the two UK cases were discussed in an interview with the Danish enforcer, and s/he was asked whether the preparation of a similar annual report, in which more commentary appeared in the notes section, would cause problems in Denmark:

This is clearly problematic. You are not allowed to do that. [... The management commentary must be reported separately and should not be audited. So it cannot be part of material [the notes] that must be audited. (Z1) 
There are elements of mythologizing the Danish enforcer, as noted by the enforcers themselves, who suggest that their stances towards materiality thresholds (for disclosures) and alternative reporting formats are rarely tested:

\begin{abstract}
We have been accused of having a low materiality threshold, but it is really difficult. There are few companies that challenge us and argue that they sincerely believe a disclosure item is immaterial. [...] Our response to a general critique is that companies have to write to us with specific examples of disclosures that are considered immaterial. (Z2)
\end{abstract}

It was also indicated that the Danish regulator was open to dialogue and that it was possible to obtain pre-clearance for specific considerations related to IFRS. According to the Danish enforcer, very few companies approached the enforcer for opinions or informal pre-clearance. Rather, it was mainly auditors that occasionally approached the enforcer. Like the Danish enforcer, the UK enforcer suggested that companies had to be proactive in addressing materiality, but the UK enforcer indicated an intention to encourage such proactiveness:

\begin{abstract}
It is essentially the company's responsibility to conclude what is material and what is not material, and then it is our job to question that. We do not want to put ourselves in their place, so we will quite often accept the company's view on whether something is not material. [...] I think that there is still a way to go; there are still people who are hesitant to embrace that. I think they are probably still a bit nervous. The FRC still has quite a lot to do to encourage people not to fear that, if they take out immaterial information, they will get a letter from us. I think we still need to work on that. It will take a period of years. (Z4)
\end{abstract}

Such encouragement was perceived in the range of corporate reporting publications by regulators (FRC, 2009; FRC, 2011; FRC, 2012) and in the establishment of the financial reporting lab. These publications clarified enforcer attitudes, and enforcer behaviour became more predictable. In addition, the publications provided support for company staff to propose changes and to show top management and the board that the implementation of these changes was a legitimate exercise.

In contrast to the FRC, the Danish regulator did not consider such encouragement appropriate.

You do not provide advice about what they [preparers] could do [to improve the annual report]. It is not our job. Company management is responsible for the annual report. They should provide the good ideas, and we must evaluate whether they provide a 'true and fair view'. (Z1)

\title{
4.2.2 Climate of defensiveness
}

Several individuals involved in the annual report preparation process in the Danish cases were resistant to a shift away from defensiveness, even as they envisaged changes to the annual report and considered disclosure content ineffective and immaterial. A key reason for this resistance, as Power (2004a) argued, is that preoccupation with reputation and penalties turns the accounting concept of materiality upside down. This argument is related to the imbalance between the magnitude of potential wrongdoing and the magnitude of the consequences of such wrongdoing. When the sanctions for omitted disclosures are harsh, or if there is uncertainty about the requirements, compliance 
motivations are negative (May, 2004), and regulatees are likely to choose the most conservative behaviour (Schwarcz, 2009). Thus, although the true-and-fair objective of the annual report implies that only material disclosures are reported and that immaterial information remains undisclosed, the defensive environment observed in the Danish case companies suggests that the line between what is and is not material is drawn well below the threshold that preparers deem appropriate. The reason for this low threshold is that even small deviations from disclosure requirements might have significant reputational consequences if these departures are considered non-compliance by the regulator.

In other words, the risk of being blamed for a 'type 2' error (i.e., concluding that information is immaterial when in fact it is material) is perceived as much more critical than the risk of committing a 'type 1' error (i.e., concluding that something is material when in fact it is immaterial). Further, there is no basis for concluding that regulators or auditors consider the latter type to be an error at all. Bloomfield (2012) referred to the failure to discourage immaterial disclosures as the 'one-sidedness' of disclosure regulations, which only augments perceptions of disclosure overload. In contrast, this one-sidedness might be justified on the grounds that users of annual reports should be protected to a greater extent from non-disclosure than from the disclosure of immaterial information (ICAEW, 2013).

The UK case companies were also concerned with these issues and the potential cost of reputational damage. However, this concern was allayed by the explicit comfort provided by national regulators and, in one case, direct discussions with the regulator as 'informal pre-clearance'. From this perspective, the apparent obsession with reputation risks might not be so difficult to counteract. Much seems to be possible through a reconsideration of regulator behaviour and, arguably even more effective, a rhetorical change aimed at mitigating myth building. It thus appears that the financial reporting environment in the UK has made more progress in establishing what Bebbington et al. (2012) referred to as a 'normative climate' or in developing 'social norms', which Sunder (2010) suggested should exist alongside written rules to counteract defensive behaviour.

\subsection{Beliefs and Attitudes}

4.3.1 The extent to which current disclosure requirements are considered meaningful Preparers in both countries suggested that disclosure requirements had gone too far and included an excessive number of detailed prescriptions:

IFRS requires an extreme amount of detailed information, and the focus seems to be on the 'bookkeeping system' rather than on what is actually material. [...] I believe that IFRS needs to revise its disclosures. They are too extensive and do not provide material information. (D2)

Regarding IFRS disclosures in general, I think that you are required to include a ridiculous amount of information on share-based payments that no one understands, all of the performance terms, periods and expected volatilities ... I mean, really? What does that mean? Does anyone that looks at these accounts really use any of that information? I would argue that they don't, but you have to put it in. It takes up two pages, and no one reads it. (F2) 
Understanding disclosure requirements was considered by some respondents to be so burdensome that it wasted energy which could have been used for thoughtful application and reflection:

We are down for a long time when IFRS establishes new requirements. (A2)

IASB claims that they make principles-based standards. The standards may be short, but if you consider, for example, IAS 39, which at about 50 paragraphs is not especially long, its application guidance comprises about 200 pages. So although IASB makes principles-based standards, they also provide many examples on how to apply the standard. (C2).

Arguably, the use of checklists and IFRS reviews conducted by auditors eliminated some of the concerns about the inability to understand disclosure requirements. Thus, to some extent, companies have decided to provide mechanical responses to disclosure regulations, instead of attempting to elaborate on disclosures, eliminating unnecessary information based on materiality judgements and changing the form and content of disclosures. Nonetheless, there was criticism of not only the overwhelming number of disclosure requirements but also of the resources spent to comply with them:

It is extremely expensive to prepare note disclosures. Awfully expensive. [...] The audit is a very small part of the total cost of disclosures. The preparers spend significant resources on disclosures. (Y4)

Disclosures regarding pensions, financial instruments and share-based payments were cited most often by interviewees as being burdensome and likely to be of limited stakeholder interest.

\subsubsection{The role and understanding of users' information needs}

The analysed cases suggest that user needs and the appropriate means to address these needs in company disclosures are far from clear for preparers, in contrast to the assumptions of regulators, accounting firms and organizations that are calling for changes to address user needs. The extent to which the disclosures of case companies met analyst needs did not appear to be well defined among the interviewed analysts. Although the analysts could articulate only a few specific disclosure areas that could be improved, they expressed profound dissatisfaction with case company disclosures and with corporate reporting practices in general. Despite this stated dissatisfaction, the issue did not seem to be a major concern for them, and many of them simply used other information sources that were better or more convenient.

....it is just because I am lazy that I call the company and get the information that I could obtain from reading the annual report more carefully. (X1)

The financial reporting feedback from analysts was limited in all cases.

They [analysts] don't care about what the back end [the notes section] is like. They need numbers in models, and they get that information from coming to the analyst presentations. (F2)

The feedback you obtain [from analysts and investors] is very limited [...], and if you ask investors and analysts what they think about the annual report, you will get the answer: "Well, we think that it's fine”. (D1) 
There appeared to be several explanations for why annual report disclosures were not a significant concern for analysts. First, analysts seemed more concerned that the nature and location of disclosures in the annual report did not change from year to year, indicating that users prefer to receive disclosures with which they are familiar and do not necessarily want improved disclosures that might better meet user needs. Furthermore, whether disclosures (in the notes) could be reconciled with other information was considered important. The reconciliation of disclosures with other more verifiable information increases the reliability of these disclosures. Thus, as Clor-Proell (2009) demonstrated in an experimental setting, the primary concern of users is whether disclosures deliver what is expected by users.

Second, analysts generally did not demand better disclosures because it was the analysts' job, as information intermediaries, to develop an informational advantage:

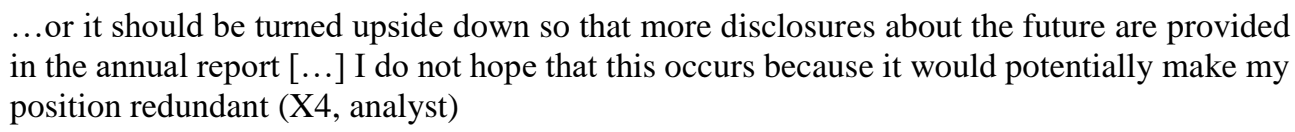

Third, certain disclosure requirements are viewed as policy instruments, in the sense that disclosure requirements are used as an alternative to other policy instruments and not as requirements designed to satisfy users' demands for information. This perception appears to motivate several disclosures related to executive compensation (see Enriques and Gilotta, 2015, for a review of the use of disclosure as a policy instrument). In this light, it is perhaps not surprising that preparers experienced little user interest or even found it difficult to imagine the extent to which such disclosures were used by stakeholders.

Previous research has demonstrated that stakeholders have different interests in the form and content of the annual report (Barker et al., 2013). Research has also shown that user needs and preferences are not well understood but rather are constructed during the process of producing and interpreting disclosure regulations (Young, 2006). The cases also indicate that conceptions and understandings of annual report users are based somewhat on fabricated 'myths'. Indeed, the lack of direct interaction with users and the corresponding absence of observations about user needs at the company level are striking and are in fact similar to what has been inferred regarding the standard-setting level (Power, 2009; Young, 2006). This result is surprising because company-level preparers should be quite close to the actual users of annual reports.

\subsection{Roles, hierarchies and conflicts}

Gibbins et al. (1990) noted that annual report preparation often involves broad circulation of draft disclosures, as well as a division of responsibility for different parts of the report. In all six cases, there were two dominant functional groups involved in annual report preparation: the investor relations and finance departments. The former handled the management commentary, whereas the latter concentrated primarily on the notes. Employees from investor relations and finance are not always 'best friends', as most harshly expressed by interviewees in case C: 
When I started, there were people who proudly stated that they had prepared the same thing as last year. The accounting department is the most conservative unit in the group. They don't drive anything - except to do what they are told by the auditors. (C1)

There shouldn't be any IR function. If so, it should be a sub-unit of the accounting department. (C2)

In some cases, this animosity led to disrespect for disclosures prepared by other functional groups:

The problem is that this document [the annual report] is one in which people normally have faith. It has a high degree of validity, and the more junk you add to the report, the less valid it becomes. Take our CSR report as an example - only a small fraction of the numbers reported are actually valid. Most of the CSR report is written by journalists for other journalists. If possible, I would skip this junk [CSR disclosure] in my [annual] report. I don't think I can say it more clearly. (C2)

The perception that no functional area is given primary responsibility for the annual report and that the preparation process involves input from diverse functional areas also appeared in other cases. In general, the dispersed input to the annual report form and content generated competition for space and priorities in the annual report. It is striking that, in the two UK cases, the overall responsibility for the annual report, including both the management commentary and the notes, was assigned to a single functional group: the investor relations group. In the UK cases, investor relations directed more or less formal change projects that included dedicated funding and participation of stakeholders across the company.

One of the main differences between the approaches taken by accountants and investor relations personnel appeared to be that accountants adopted a 'compliance view' of annual report preparation, whereas investor relations staff claimed to adopt a 'user view'. The 'compliance view' was expressed as a perceived responsibility to be absolutely sure to comply with IFRS. This view did not appear to be guided by considerations of how to adopt or respond to regulations while meeting the needs of company constituencies; rather, the stated aim was to avoid trouble and the risk that others could identify deficiencies or other shortcomings in the annual report. Accountants feared not only problems with financial reporting enforcement but also that auditors would escalate an IFRS disagreement to executive management.

The perceived burden of IFRS disclosure requirements was cited as a key explanation for the paucity of interest in developing the notes section in the Danish cases. Cases B and D devoted considerable resources to the management commentary, whereas in cases A and $\mathrm{C}$, there appeared to be limited resources available for developing disclosures because top management did not prioritize the annual report. In the latter cases, changing the annual report was viewed as depleting additional resources that were currently unavailable:

It does require a lot of resources to change it all and do things in a different way. So this is not something you just do. In any case, we do not have the resources to do it; it is a matter of the top management's level of ambition. (A1)

According to the head of investor relations in case A, one explanation for the lack of resources is that the individuals involved in the preparation process are in support 
functions, which do not generate revenue and therefore have tight budgets. An interviewee at company $\mathrm{C}$ suggested that resource efficiency was an important rationale for the annual report and that efficiency was demanded by internal constituencies.

In other cases, the efficient use of time and resources to prepare disclosures appeared to be a key priority for several company staff members. This efficiency was sought by, for example, keeping disclosures consistent, making changes to disclosures only when necessary to accommodate new requirements and repeating the text of disclosures made in previous years. The aim of resource efficiency appeared to be a significant barrier to new disclosures:

I have no interest in collecting information from 150 companies within the group every time somebody asks for further disclosures. You must evaluate such requests based on 'nice to know' and 'need to know'. (A2)

Boards of directors, their audit committees and executives are formally those that prepare and sign the annual report. Although these individuals are not always involved in the hands-on work, their attitudes can significantly influence the finished product (Adams, 1997; Gibbins et al., 1990). In several case companies, top management neither played a major role in the preparation process nor initiated changes. Rather, high-level managers appeared to influence the annual report through their personal views about certain disclosures and a general resistance to changes in the form and content of the annual report:

...we have tried to make some changes, which we included in our first draft, but they were removed [by the management]. (A2)

Although management resistance to change was most explicit in case A and the staff in case A pre-emptively excluded the possibility of making substantial changes to the annual report, interviewees in each Danish case reported instances of management resistance.

In cases A-D, the annual report was prepared mainly by staff at hierarchical levels below the executive level. In these cases, the CFO, other executives and the board of directors were typically not involved until late in the process. In contrast, in the UK cases, the audit committee chair (case E) and the CFO (cases E and F) were involved in both the initiation of changes and the preparation process. As a result, the commitment and attitudes of directors and top management were obvious to the staff, eliminating the need for second guessing during the preparation process.

Also notable are the organizational levels at which key decisions in the annual report preparation processes are made. In the four Danish case companies, top management approved draft templates and the final annual report, but choices regarding the design and content of disclosures were made by other staff. One root cause of a defensive approach to annual reports might be that the staff members involved in preparation, who might be several tiers below the executive level, must justify their decisions to regulators, auditors, executives and board members. This need for justification develops an environment comparable to what Power (2004b) called the culture of defensiveness, which is driven by individuals who avoid making judgements because they are preoccupied with the risk of jeopardizing their reputations. 
A summary of the main barriers to and enablers of change in the notes section is shown in table 3.

Table 3. Barriers to and enablers of annual report changes

\begin{tabular}{|l|ll|l|}
\hline & Barriers & Enablers \\
\hline $\begin{array}{l}\text { Regulatory } \\
\text { practices }\end{array}$ & $\bullet \begin{array}{l}\text { Auditor preoccupation with conservative } \\
\text { compliance }\end{array}$ & $\begin{array}{l}\bullet \\
\text { The perceived materiality threshold of } \\
\text { enforcers } \\
\text { Mythologizing financial reporting }\end{array}$ & $\begin{array}{l}\text { Using blueprints from regulators to } \\
\text { legitimize changes }\end{array}$ \\
\hline $\begin{array}{l}\text { Beliefs } \\
\text { and } \\
\text { attitudes }\end{array}$ & $\bullet \begin{array}{l}\text { IFRS disclosure requirements are } \\
\text { perceived as overwhelming }\end{array}$ & $\begin{array}{l}\text { Perceived benefits of appearing innovative } \\
\text { and a belief in providing investors with an } \\
\text { authoritative source of information }\end{array}$ \\
\hline Abilities & $\bullet \begin{array}{l}\text { Lack of interest and support from top } \\
\text { management for annual report changes } \\
\text { Dispersion of responsibility }\end{array}$ & $\begin{array}{l}\text { Tone from the top } \\
\text { Establishing and managing a change } \\
\text { project with dedicated funding } \\
\text { Assigning responsibility to a single } \\
\text { functional group }\end{array}$ \\
\hline
\end{tabular}

\section{CONCLUDING REMARKS}

This study identifies a number of barriers to as well as enablers of annual report reform. The findings demonstrate how disclosure choices might be negatively motivated and that the preparation of the notes section involves a defensive approach to regulation. In such a context, principles-based accounting seems far away. Although an immediate explanation for this defensiveness appears to be the behaviours of regulators and auditors, it also seems to be driven by the preparers themselves, based on their belief that principles-based considerations (materiality judgements in particular) require too much time and effort. For most of the Danish interviewees, the use of checklists and 'box ticking' was a way to get things done because it obviated the need to make difficult and time-consuming materiality judgements. It was often more convenient for staff to mechanically comply with each disclosure requirement, and the lack of interest and support from top management did not help in this regard.

Barriers to change were further related to internal politics, including disagreements among board members, executives, financial staff, investor relations, other functional areas and auditors. Such disagreements create internal uncertainty (Berland et al., 2015), typically related to individual preferences, and they explain why changes are not pursued, despite recognition by the company interviewees of the need for reform. Furthermore, the beliefs and attitudes across both countries about IFRS regulation were not enthusiastic and evoked negative compliance motivations. Barriers also included limited attention from users of the notes section, which left preparers with some doubt about whether users would respond positively to a change in the form and content of the notes.

Enablers of change were related to positive compliance motivations and seemed to be developed from primarily a perception of the regulator as facilitative and not overly rigid. 
In addition, the perceived benefits of being among the first companies to implement specific changes to the annual report should not be underestimated. Finally, a shared understanding among the investor relations staff, the accounting department and top management seems to foster an environment conducive to thinking and working proactively with annual report regulations.

The behaviour of regulators in the UK is perceived to be more predictable and supportive than that of Danish regulators. Although there is evidence to suggest the mythologization of the Danish enforcer, there seems to be a difference in the positions of UK and Danish enforcers along the two enforcement-style dimensions, namely the degree of facilitation and the degree of formalism (May, 2004). Power (2004a) appeared to be correct that a move away from a defensive approach to compliance is likely to require fundamental trust in the honest judgements of experts and practitioners, i.e., auditors and preparers. Although it might be rhetorical in nature, there is a difference between the views expressed by enforcers in Denmark and the UK regarding their trust in the judgements of preparers. The Danish enforcer suggested that regulators had their own views of what is material and that this view was used to challenge preparers, whereas the UK enforcer did not express a need to form an independent view of materiality but rather generally chose to rely on preparer judgements.

This study adds to the literature by examining the manner in which preparers respond to regulations in the notes section and by identifying barriers and enablers associated with the potential of changing the form and content of notes. It further adds by exposing the interrelationships among macro-level institutions and micro-level actors and activities, which to date have attracted only limited attention in the financial reporting field (Chahed and Goh, 2016; Lounsbury, 2008). Further, the study shows how contextual factors can impact motivations to comply with disclosure regulations. The study also contributes to practice by showing, in the UK case studies, that when regulators debate current practices and encourage an annual report reform, it is possible to create an environment that facilitates annual report changes. The trust and predictability of regulators and the support of top management were important instruments in this regard. Furthermore, preparers who consider their primary objective to be meeting the needs of annual report users rather than the needs of regulators could signal a shift away from defensiveness (May, 2004; Power, 2004b). Furthering this shift will require the active participation of managers in the preparation process (Gibbins et al., 1990). In this type of environment, company staff members appeared to be less concerned about the reputational risk of wrongdoing and more concerned about developing annual reports that met users' needs. Regarding disclosure requirements, although their limited legitimacy is a barrier to annual report reform, we concur with Barker et al. (2013) that IFRS and other accounting regulations are not the only reason - and probably not even the main reason - for disclosure overload. Our findings suggest that the enforcement styles of regulators and auditors and the annual report preparation process itself are counterproductive to the resolution of disclosure overload.

This research can be extended in several respects. First, it is striking that analysts are uninterested in annual report reform. Their lack of interest stands in stark contrast to the articulated need for annual report changes to meet user needs. Future studies could therefore further address this apparent discrepancy. Second, the findings suggest that 
regulators and their enforcement styles play important roles in annual report reform. It is therefore important to further understand how and why certain regulators successfully facilitate annual report changes, whereas others (intentionally or unintentionally) develop antagonistic relationships with regulatees.

\footnotetext{
${ }^{1}$ Lowe et al. (2016) argued that it is problematic to distinguish between domain and method theories in explaining the theoretical contribution (to a domain). While we have no intention of engaging in this discussion, we believe that it is useful to understand 'method theory' as a theory from another domain (regulation) from which the financial reporting domain might benefit (Lowe et al., 2016, p. 307; Lukka and Vinnari, 2014, p. 1309).

${ }^{2}$ The main disclosure requirements are found in IAS 1 (basis of preparation, key accounting estimates, special items, contingencies), IFRS 2 (share-based payment), IFRS 3 (business combinations), IFRS 7 (financial instruments), IFRS 8 (operating segments), IAS 12 (taxes), IAS 19 (pensions), IAS 24 (related parties, board/executive compensation), IAS 36 (impairment test) and a few requirements originating from the EU accounting directives and implemented in national law (e.g., audit fees).

${ }^{3}$ These statements were made by the Danish enforcer at a workshop organized by an accounting firm.
} 


\section{REFERENCES}

Adams, M. (1997), "Ritualism, opportunism and corporate disclosure in the New Zealand life insurance industry: field evidence", Accounting, Auditing \& Accountability Journal, Vol. 10 No. 5, pp. 718-734.

Alon, A. (2013), "Complexity and dual institutionality: The case of IFRS adoption in Russia", Corporate Governance: An International Review, Vol. 21 No. 1, pp. 42-57.

Baldwin, R., Cave, M., and Lodge, M. (2011), Understanding regulation: theory, strategy, and practice, Oxford University Press, Oxford.

Barker, R., Barone, E., Birt, J., Gaeremynck, A., Mcgeachin, A., Marton, J., \& Moldovan, R. (2013), "Response of the EAA FRSC to the EFRAG/ANC/FRC Discussion Paper: Towards a Disclosure Framework for the Notes", Accounting in Europe, Vol. 10 No. 1, pp. 1-26.

Baxter, J. A. \& Chua, W. F. (1998), "Doing Field Research: Practice and Meta-Theory in Counterpoint", Journal of Management Accounting Research, Vol. 10, pp. 69-87.

Beattie, V., Fearnley, S., and Hines, T. (2011), Reaching key financial reporting decisions: how directors and auditors interact, Wiley, West Sussex.

Beattie, V. (2014), "Accounting narratives and the narrative turn in accounting research: Issues, theory, methodology, methods and a research framework", The British Accounting Review, Vol. 46 No. 2, pp. 111-134.

Bebbington, J., Kirk, E. A., \& Larrinaga, C. (2012), "The production of normativity: A comparison of reporting regimes in Spain and the UK", Accounting, Organizations and Society, Vol. 37 No. 2, pp. 78-94.

Berland, N., Levant, Y., \& Zelinski, D. (2015), Beyond Window Dressing: Competing Institutional Logics and Decoupling - The Case of IFRS 8, Proceedings, Interdisciplinary Perspectives on Accounting Conference, Stockholm, Sweden.

Beyer, A., Cohen, D. A., Lys, T. Z., \& Walther, B. R. (2010), "The financial reporting environment: Review of the recent literature", Journal of Accounting and Economics, Vol. 50 No. 2, pp. 296-343.

BIS (2013), Government response: Accounting standards are part of legally binding corporate reporting framework, Statement from Jo Swinson, Minister for Employment Relations and Consumer Affairs, Department for Business, Innovation \& Skills.

Bischof, J. (2009), "The Effects of IFRS 7 Adoption on bank disclosure in Europe", Accounting in Europe, Vol. 6 No. 2, pp. 167-194.

Black, J. (2008a), "Constructing and contesting legitimacy and accountability in polycentric regulatory regimes", Regulation \& Governance, Vol. 2 No. 2, pp. 137-164. 
Black, J. (2008b), "Forms and paradoxes of principles-based regulation", Capital Markets Law Journal, Vol. 3 No. 4, pp. 425-457.

Bloomfield, R. J. (2012), "A pragmatic approach to more efficient corporate disclosure", Accounting Horizons, Vol. 26 No. 2, pp. 357-370.

Bozanic, Z., Dirsmith, M. W., \& Huddart, S. (2012), "The social constitution of regulation: The endogenization of insider trading laws", Accounting, Organizations and Society, Vol. 37 No. 7, pp. 461-481.

Braithwaite, V., Murphy, K., \& Reinhart, M. (2007), "Taxation threat, motivational postures, and responsive regulation", Law \& Policy, Vol. 29 No. 1, pp. 137-158.

Canning, M. \& O'Dwyer, B. (2016), "Institutional work and regulatory change in the accounting profession", Accounting, Organizations and Society, Vol. 54 No. October, pp. $1-21$.

Carpenter, V. L. \& Feroz, E. H. (2001), "Institutional theory and accounting rule choice: an analysis of four US state governments' decisions to adopt generally accepted accounting principles", Accounting, Organizations and Society, Vol. 26 No. 7, pp. 565596.

Chahed, Y. \& Goh, L. (2016), "Disclosure as Collective Work: Skill and knowledge sharing in the corporate reporting process", Available at SSRN 2316972.

Chell, E. (1998), "Critical Incident Technique in Symon, G. and Cassell, C. (Eds) Qualitative Methods and Analysis in Organizational Research Sage, London, pp. 51-72.

Clor-Proell, S. M. (2009), "The effects of expected and actual accounting choices on judgments and decisions", The Accounting Review, Vol. 84 No. 5, pp. 1465-1493.

Cohen, J. R., Krishnamoorthy, G., Peytcheva, M., \& Wright, A. M. (2013), "How Does the Strength of the Financial Regulatory Regime Influence Auditors' Judgments to Constrain Aggressive Reporting in a Principles-Based Versus Rules-Based Accounting Environment?", Accounting Horizons, Vol. 27 No. 3, pp. 579-601.

Cooper, D. J. \& Robson, K. (2006), "Accounting, professions and regulation: Locating the sites of professionalization", Accounting, Organizations and Society, Vol. 31 No. 45, pp. 415-444.

Corley, K. G. \& Gioia, D. A. (2011), "Building theory about theory building: what constitutes a theoretical contribution?", Academy of Management Review, Vol. 36 No. 1, pp. 12-32.

Cormier, D., Gordon, I. M., \& Magnan, M. (2004), "Corporate environmental disclosure: contrasting management's perceptions with reality", Journal of Business Ethics, Vol. 49 No. 2, pp. 143-165. 
Cormier, D., Magnan, M., \& Van Velthoven, B. (2005), "Environmental disclosure quality in large German companies: economic incentives, public pressures or institutional conditions?", European Accounting Review, Vol. 14 No. 1, pp. 3-39.

Covaleski, M. A., Dirsmith, M. W., \& Weiss, J. M. (2013), "The social construction, challenge and transformation of a budgetary regime: The endogenization of welfare regulation by institutional entrepreneurs", Accounting, Organizations and Society, Vol. 38 No. 5, pp. 333-364.

Edelman, L. B. \& Suchman, M. C. (1997), "The legal environments of organizations", Annual Review of Sociology, Vol. 23 No. 1, pp. 479-515.

Edelman, L. B. \& Talesh, S. A. (2011), "To comply or not to comply - That isn't the question: How organizations construct the meaning of compliance in Parker, C. and Nielsen, V. L. (Eds) Explaining Compliance: Business Responses to Regulation Edward Elgar, Cheltenham, pp. 103-122.

Edgley, C. (2014), "A genealogy of accounting materiality", Critical Perspectives on Accounting, Vol. 25 No. 3, pp. 255-271.

EFRAG, ANC, \& FRC (2012), Towards a disclosure framework for the notes: discussion paper, European Financial Reporting Advisory Group, Autorité des Normes Comptables and the UK Financial Reporting Council, Brussels, Paris and London.

EFRAG \& ASB (2011), Considering the effects of accounting standards: discussion paper, European Financial Reporting Advisory Group and Accounting Standards Board, Financial Reporting Council, Brussels and London.

Eng, L. L. \& Mak, Y. T. (2003), "Corporate governance and voluntary disclosure", Journal of Accounting and Public Policy, Vol. 22 No. 4, pp. 325-345.

Enriques, L. \& Gilotta, S. (2015), "Disclosure and financial market regulation in Moloney, N. et al. (Eds) The Oxford Handbook of Financial Regulation Oxford University Press, Oxford, pp. 511-536.

Etienne, J. (2011), "Compliance theory: A goal framing approach", Law \& Policy, Vol. 33 No. 3, pp. 305-333.

Fearnley, S., Hines, T., McBride, K., \& Brandt, R. (2000), A peculiarly British institution. An Analysis of the contribution made by the Financial Reporting Review Panel to accounting compliance in the UK, Institute of Chartered Accountants in England and Wales.

Fearnley, S., Hines, T., McBride, K., \& Brandt, R. (2002), "The impact of the Financial Reporting Review Panel on aspects of the independence of auditors and their attitudes to compliance in the UK", The British Accounting Review, Vol. 34 No. 2, pp. 109-139.

Fox, K. \& Cooper, D. (2015), Framing Key Metrics, Proceedings, Interdisciplinary Perspectives on Accounting Conference, Stockholm, Sweden. 
FRC (2009), Louder than words: principles and actions for making corporate reports less complex and more relevant, Financial Reporting Council, London.

FRC (2011), Cutting clutter: combating clutter in annual reports, Financial Reporting Council, London.

FRC (2012), Thinking about disclosures in a broader context, Financial Reporting Council, London.

Gibbins, M., Richardson, A., \& Waterhouse, J. (1990), "The management of corporate financial disclosure: opportunism, ritualism, policies, and processes", Journal of Accounting Research, Vol. 28 No. 1, pp. 121-143.

Gilad, S. (2014), "Beyond Endogeneity: How Firms and Regulators CoGÇÉConstruct the Meaning of Regulation", Law \& Policy, Vol. 36 No. 2, pp. 134-164.

Glaum, M., Schmidt, P., Street, D. L., \& Vogel, S. (2013), "Compliance with IFRS 3-and IAS 36-required disclosures across 17 European countries: company-and country-level determinants", Accounting and Business Research, Vol. 43 No. 3, pp. 163-204.

Goodstein, J. D. (1994), "Institutional pressures and strategic responsiveness: employer involvement in work-family issues", Academy of Management Journal, Vol. 37 No. 2, pp. 350-382.

Gray, S. J., Radebaugh, L. H., \& Roberts, C. B. (1990), "International perceptions of cost constraints on voluntary information disclosures: a comparative study of UK and US multinationals", Journal of International Business Studies, Vol. 21 No. 4, pp. 597-622.

Greenwood, R. \& Suddaby, R. (2006), "Institutional entrepreneurship in mature fields: The big five accounting firms", Academy of Management Journal, Vol. 49 No. 1, pp. 2748.

Greenwood, R., Suddaby, R., \& Hinings, C. R. (2002), "Theorizing change: The role of professional associations in the transformation of institutionalized fields", Academy of Management Journal, Vol. 45 No. 1, pp. 58-80.

Gué-Paracini, H., Malsch, B., \& Paillé, A. M. (2014), "Fear and risk in the audit process", Accounting, Organizations and Society, Vol. 39 No. 4, pp. 264-288.

Guerreiro, M. S., Rodrigues, L. c. L., \& Craig, R. (2012), "Voluntary adoption of International Financial Reporting Standards by large unlisted companies in Portugal: Institutional logics and strategic responses", Accounting, Organizations and Society, Vol. 37 No. 7, pp. 482-499.

Gunningham, N., Kagan, R. A., \& Thornton, D. (2004), "Social license and environmental protection: why businesses go beyond compliance", Law \& Social Inquiry, Vol. 29 No. 2, pp. 307-341. 
Hatherly, D., Leung, D., \& MacKenzie, D. (2008), "The finitist accountant in Pinch, T. and Swedberg, R. (Eds) Living in a material world: On the mutual constitution of technology, economy, and society MIT Press, Boston, MA, pp. 131-160.

Hines, T., McBride, K., Fearnley, S., \& Brandt, R. (2001), "We're off to see the wizard: An evaluation of directors' and auditors' experiences with the Financial Reporting Review Panel", Accounting, Auditing \& Accountability Journal, Vol. 14 No. 1, pp. 53-84.

Hooghiemstra, R. \& van Ees, H. (2011), "Uniformity as response to soft law: Evidence from compliance and non-compliance with the Dutch corporate governance code", Regulation \& Governance, Vol. 5 No. 4, pp. 480-498.

Hope, O. K. (2003), "Disclosure practices, enforcement of accounting standards, and analysts' forecast accuracy: An international study", Journal of Accounting Research, Vol. 41 No. 2, pp. 235-272.

Huikku, J., Mouritsen, J., \& Silvola, H. (2017), "Relative reliability and the recognisable firm: Calculating goodwill impairment value", Accounting, Organizations and Society, Vol. 56 No. January, pp. 68-83.

IAASB (2012), The evolving nature of financial reporting: disclosure and its audit implications - feedback statement, International Auditing and Assurance Standards Boards, International Federation of Accountants, New York.

IASB (2011), Effect analysis: IFRS 10 Consolidated financial statements and IFRS 12 Disclosure of interests in other entities, International Accounting Standards Board, London.

IASB (2014), ED/2014/1 Disclosure Initiative (Amendments to IAS 1), International Accounting Standards Board, London.

IASB (2015), IFRS Practice Statement: Application of materiality to financial statements, IFRS Foundation, Exposure draft ED/2015/8.

ICAEW (2013), Financial Reporting Disclosures: Market and Regulatory Failures, ICAEW Financial Reporting Faculty, London.

Johansen, T. R. \& Plenborg, T. (2013), "Prioritising disclosures in the annual report", Accounting and Business Research, Vol. 43 No. 6, pp. 605-635.

Kvale, S. (1996), InterViews, Sage, Thousand Oaks, California.

Lantto, A. M. (2013), "Business Involvement in Accounting: A Case Study of International Financial Reporting Standards Adoption and the Work of Accountants", European Accounting Review, Vol. 23 No. 2, pp. 335-356.

Laughlin, R. (1995), "Empirical research in accounting: alternative approaches and a case for middle range thinking", Accounting, Auditing \& Accountability Journal, Vol. 8 No. 1, pp. 63-87. 
Leung, D. (2011), Inside Accounting: The Sociology of Financial Reporting and Auditing, Gower Publishing, Ltd..

Leuz, C. \& Wysocki, P. (2016), "The economics of disclosure and financial reporting regulation: Evidence and suggestions for future research", Journal of Accounting Research, Vol. 54 No. 2, pp. 525-622.

Lounsbury, M. (2008), "Institutional rationality and practice variation: New directions in the institutional analysis of practice", Accounting, Organizations and Society, Vol. 33 No. 4, pp. 349-361.

Lowe, A. D., De Loo, I., \& Nama, Y. (2016), "Cutting the Gordian knot [?]: a response to Lukka and Vinnari (2014)", Accounting, Auditing \& Accountability Journal, Vol. 29 No. 2, pp. 305-316.

Lukka, K. \& Vinnari, E. (2014), "Domain theory and method theory in management accounting research", Accounting, Auditing \& Accountability Journal, Vol. 27 No. 8, pp. 1308-1338.

MacKenzie, D. (2008), "Producing accounts: finitism, technology and rule-following in Mazzotti, M. (Ed) Knowledge as social order Ashgate, Hampshire, pp. 99-118.

Martin, A. D. \& Hadley, D. J. (2008), "Corporate environmental non-reporting - a UK FTSE 350 perspective", Business Strategy and the Environment, Vol. 17 No. 4, pp. 245259.

May, P. J. (2004), "Compliance motivations: Affirmative and negative bases", Law \& Society Review, Vol. 38 No. 1, pp. 41-68.

May, P. J. \& Winter, S. C. (2011), "Regulatory enforcement styles and compliance in Parker, C. and Nielsen, V. L. (Eds) Explaining Compliance: Business Responses to Regulation Edward Edgar, Cheltenham, pp. 222-244.

Mayorga, D. (2013), "Managing continuous disclosure: Australian evidence", Accounting, Auditing \& Accountability Journal, Vol. 26 No. 7, pp. 1135-1169.

NZCA \& ICAS (2011), Losing the excess baggage - reducing disclosures in financial statements to what's important, New Zealand Institute of Chartered Accountants and The Institute of Chartered Accountants of Scotland, Napier and Edinburgh.

O'Dwyer, B. (2004), "Qualitative data analysis: illuminating a process for transforming a 'messy' but 'attractive' nuisance in Humphrey, C. and Lee, B. (Eds) The real life guide to accounting research: A behind-the-scenes view of using qualitative research methods Elsevier, Oxford, pp. 391-407.

O'Dwyer, B. \& Unerman, J. (2014), "Realizing the potential of interdisciplinarity in accounting research", Accounting, Auditing \& Accountability Journal, Vol. 27 No. 8, pp. $1227-1232$. 
Oliver, C. (1991), "Strategic responses to institutional processes", Academy of Management Review, Vol. 16 No. 1, pp. 145-179.

Power, M. (2004a), "The nature of risk: The risk management of everything", Balance Sheet, Vol. 12 No. 5, pp. 19-28.

Power, M. (2004b), The risk management of everything, Demos, London.

Power, M. (2007), Organized uncertaincy: Designing a world of risk management, Oxford University Press, Oxford.

Power, M. (2009), "Financial accounting without a state in Chapman, C. S. et al. (Eds) Accounting, Organizations, and Institutions: Essays in honour of Anthony Hopwood Oxford University Press, Oxford, pp. 324-341.

Quaak, L., Aalbers, T., \& Goedee, J. (2007), "Transparency of corporate social responsibility in Dutch breweries", Journal of Business Ethics, Vol. 76 No. 3, pp. 293308.

Robson, K. \& Young, J. (2009), "Socio-political studies of financial reporting and standard-setting in Chapman, C. S. et al. (Eds) Accounting, Organizations, and Institutions: Essays in the honour of Anthony Hopwood Oxford University Press, Oxford, pp. 341-366.

Robson, K., Young, J., \& Power, M. (2017), "Themed Section on Financial Accounting as Social and Organizational Practice: Exploring the work of financial reporting", Accounting, Organizations and Society, Vol. 56 No. 1, pp. 35-37.

Schipper, K. (2007), "Required disclosures in financial reports", The Accounting Review, Vol. 82 No. 2, pp. 301-326.

Schwarcz, S. L. (2009), "The 'Principles' Paradox", European Business Organization Law Review, Vol. 10 No. 2, pp. 175-184.

Spencer, J. (2014), To disclose or not to disclose: Materiality is the question, Australian Accounting Standards Board, AASB Staff Paper.

Sunder, S. (2010), "Adverse effects of uniform written reporting standards on accounting practice, education, and research", Journal of Accounting and Public Policy, Vol. 29 No. 2, pp. 99-114.

Weaver, R. K. (2014), "Compliance regimes and barriers to behavioral change", Governance, Vol. 27 No. 2, pp. 243-265.

Young, J. J. (2006), "Making up users", Accounting, Organizations and Society, Vol. 31 No. 6, pp. 579-600. 